\title{
PENGARUH MODERASI PENDEKATAN PEMBELAJARAN DALAM MENINGKATKAN KINERJA AKADEMIK MAHASISWA MELALUI MODEL GROUP INVESTIGATION
}

\author{
Theresia Hesti Bwarleling \\ Universitas Bunda Mulia \\ tbwarlelling@bundamulia.ac.id
}

\begin{abstract}
International Accounting is one of the subjects in the field of Accounting which is not enough to only be studied conceptually, as well as accounting in general. International accounting requires understanding so that later it can be applied in cases related to international trade transactions. This is because in International Accounting, students must know how accounting standards applied to each country can then be harmonized through the convergence method. In addition, students must also understand the accounting for hedging transactions, the application of transfer pricing and translation. The purpose of this study was to describe the Model Group Investigation (GI) in an effort to improve accounting learning competencies of the students of the University of Bunda Mulia Academic Year 2018/2019. The aim to be achieved in this study is to develop a model of accounting learning package as a strategy that can improve the quality of accounting learning and improve student competency in accordance with the vision and mission of the study program. Data collection methods used in this study are observation methods (through experiments), tests and documentation (questionnaire collection). In the results of this study, there was an increase in student achievement in the accounting learning process with the Group investigation learning model and this positive influence was also strengthened through the choice of the learning approach method of the students. From the tests conducted, results have been obtained in the form of significant student achievement improvement
\end{abstract}

Keyword : student competence, group investigation model, learning approach

\begin{abstract}
ABSTRAK: Akuntansi Internasional merupakan salah satu mata kuliah di bidang Akuntansi yang tidak cukup hanya dipelajari secara konseptual saja. begitu pula dengan akuntansi pada umumnya. Akuntansi Internasional memerlukan pemahaman agar nantinya dapat diaplikasikan dalam kasuskasus yang terkait dengan transaksi perdagangan internasional. Hal ini dikarenakan dalam Akuntansi Internasional, mahasiswa harus mengetahui bagaimana standar-standar akuntansi yang diterapkan pada masing-masing Negara kemudian dapat diharmonisasikan melalui metode konvergensi. Selain itu, mahasiswa juga harus memahami akuntansi atas transaksi lindung nilai, penerapan transfer pricing serta translasi. Tujuan Penelitian ini adalah untuk mendeskripsikan Model Group Investigation (GI) dalam upaya meningkatkan kompetensi belajar akuntansi para mahasiswa Universitas Bunda Mulia Tahun Ajaran 2018/2019. Tujuan yang ingin dicapai dalam penelitian ini adalah mengembangkan model paket pembelajaran akuntansi sebagai suatu strategi yang dapat meningkatkan kualitas pembelajaran akuntansi serta meningkatkan kompetensi mahasiswa yang sesuai dengan visi misi program studi. Metode pengumpulan data yang digunakan dalam penelitian ini adalah metode observasi (lewat eksperimen), tes dan dokumentasi (pengambilan kuesioner). Dalam hasil penelitian ini, terdapat peningkatan prestasi siswa dalam proses pembelajaran akuntansi dengan model pembelajaran Group investigation dan pengaruh positif ini juga diperkuat melalui pilihan metode pendekatan pembelajaran para mahasiswa. Dari tes yang dilakukan, telah diperoleh hasil berupa peningkatan prestasi siswa yang signifikan.
\end{abstract}

Kata kunci : kompetensi mahasiswa, model group investigation, pendekatan pembelajaran 


\section{Pendahuluan}

Dalam sebuah sistem pembelajaran di Perguruan Tinggi, terdapat suatu proses interaksi antara dosen dan mahasiswa yang juga ditunjang oleh unsur-unsur terkait, beberapa di antaranya adalah tujuan pembelajaran, materi pembelajaran, sarana prasarana, kondisi belajar, media pembelajaran, lingkungan belajar, metode pembelajaran, serta evaluasi pembelajaran. Beberapa unsur tersebut merupakan unsur-unsur pembelajaran yang signifikan mengarahkan proses pembelajaran menjadi lebih kondusif dan terarah serta mampu mencapai tujuan pembelajaran yang diharapkan.

Bagi mahasiswa, proses pembelajaran itu sendiri adalah suatu proses yang mentransformasikan ilmu pengetahuan dengan cara mengorganisasikan materi agar melalui penerapan pilihan metode pembelajaran yang telah ditentukan, mereka mampu memahami materi secara efektif.

$$
\text { Biggs (1979) dalam }
$$

penelitiannya, menggambarkan model pembelajaran para siswa di antaranya mencakup tiga elemen dasar, yakni input, proses, dan output. Variabel input menunjukkan isi kurikulum atau pengetahuan yang akan disampaikan kepada para siswa, sedangkan untuk elemen proses mencerminkan sarana, teknik, atau pendekatan yang nantinya akan mengubah input (yaitu pengetahuan) menjadi output. Lebih lanjut, diterangkan untuk variabel output, variabel ini merupakan kualitas atau hasil pencapaian para siswa yang berasal dari manifestasi ke-dua elemen sebelumnya (Biggs 1979). Dari ketiga elemen untuk variabel proses (sarana, teknik, dan pendekatan), pendekatan pembelajaran merupakan salah satu di antaranya dan unsur ini mendeskripsikan bagaimana cara siswa menyelesaikan proses belajar mereka (Bryne et al. 1999 dan 2002).

$$
\text { Pada penelitian-penelitian }
$$

sebelumnya yang terkait dengan pendekatan pembelajaran, beberapa peneliti telah merangkum tiga pendekatan yang umumnya diterapkan oleh para siswa yaitu; deep, instrumental (surface), dan strategic approaches (Biggs 1979; Marton dan Soljo 1976; Ramsden 1979; Enwistle 1987). Pada tahun 1976, Marton dan Soljo secara khusus, mengidentifikasi dua pendekatan dari ke-tiga pendekatan yang telah disebutkan sebelumnya di atas. Pendekatan pertama, pendekatan mendalam (deep approaches), pendekatan ini sering dikaitkan dengan metode pembelajaran para siswa yang ingin benar-benar memahami materi dengan mencoba mengintegrasikan materi pelajaran dengan mata pelajaran lain yang relevan. Dengan kata lain, ini adalah proses pembelajaran di mana siswa aktif berpartisipasi, menghubungkan pengalaman diri sendiri dan pengetahuan sebelumnya, mengekspresikan minat intrinsik dan mencari makna dari materi yang mereka pelajari (Enswistle dan Ramsden 2003; Lucas 2001; Marton dan Soljo 1976). Sebaliknya, pendekatan permukaan (instrumental-surface) adalah model pendekatan pebelajaran tanpa pemahaman yang jelas akan materi pelajaran. Pendekatan ini juga dapat diilustrasikan sebagai sebuah metode hafalan dan menghafal fakta, menguasai format, hanya dengan niat untuk mereproduksi materi yang dipelajari (Enswistle dan Ramsden 2003; Lucas 2001; Marton dan Soljo 1976). Selain dua pendekatan tersebut, Ramsden (1979) juga mengidentifikasi adanya pendekatan yang ketiga yaitu pendekatan strategis (strategic approaches), di mana siswa menyusun rancangan serta menyelesaikan target pembelajarannya sesuai dengan preferensi pengajar, dengan maksud untuk mendapatkan nilai tinggi dalam ujian. Oleh karena itu dapat disimpulkan sementara bahwa, apapun pilihan siswa dalam menentukan pendekatan pembelajaran mereka, hal tersebut 
sangatlah erat kaitannya dengan niat dan motivasi mereka dalam belajar.

Lebih lanjut, diketahui bahwa kualitas lulusan tercermin dari hasil kinerja akademik mereka (elemen output), yang memiliki hubungan langsung dengan pendekatan pembelajaran (yaitu proses) yang dijalankan oleh siswa selama mereka menyelesaikan tahapan akademik mereka (Biggs 1987a dan 1987b; Svensson 1977). Oleh karena itu, sudah saatnya penelitian-penelitian ke depan nantinya difokuskan pada kedua elemen pembelajaran, yakni proses dan output.

Perlu diperhatikan pula bahwa dalam tahapan proses sebagai salah satu elemen dasar, dosen berinteraksi dengan masingmasing mahasiswa untuk mengamati bagaimana mereka memperoleh informasi baru, membantu peserta didik merekonstruksi pengetahuan secara benar, memotivasi serta membimbing peserta didik dalam memecahkan masalah. Kehadiran

tambahan informasi dan pengalaman baru yang berasal dari seorang dosen ataupun antar sesama mahasiswa, pada akhirnya akan mengakibatkan rekonstruksi ulang pengetahuan yang lama sehingga terbentuk pengetahuan baru (Darsono, 2000). Hal ini tentunya disebabkan karena suatu proses belajar adalah perubahan menuju ke arah perkembangan yang lebih baik. Oleh karena itu faktor internal (dari dalam individu) dan faktor eksternal (dari luar individu) akan mempengaruhi keberhasilan kegiatan belajar.

Untuk mencapai kompetensi mahasiswa sesuai dengan yang diharapkan, keberadaan model pembelajaran tentunya menjadi sangat penting. Penelitian ini akan menjawab permasalahan tersebut dengan melihat bagaimana model pembelajaran yang terbaik khususnya bagi para mahasiswa akuntansi dengan menggunakan pendekatan cooperative learning, yang dimoderasi oleh pilihan pendekatan pembelajaran mereka masing-masing.

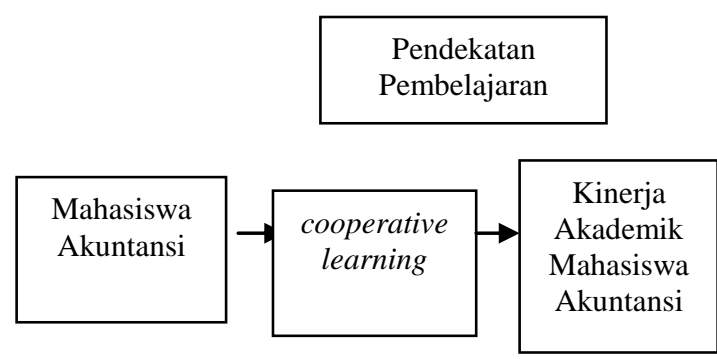

\section{Identifikasi Masalah}

Sejak munculnya penelitian tentang pendekatan para siswa dalam belajar, mulai dari awal 1970-an, telah diakui pula bahwa disiplin ilmu yang berbeda dapat mempengaruhi suasana belajar dan dengan demikian perbedaan dalam pendekatan pembelajaran siswa lintas disiplin perlu untuk diamati lebih lanjut (Entwistle dan Ramsden, 1983). Beberapa peneliti juga telah menegaskan pentingnya penelitian dalam mengeksplorasi lebih jauh pola belajar siswa pada konteks disiplin ilmu yang berbeda dan Lucas (2001) juga mendukung hal tersebut khususnya dalam pendekatan pembelajaran di bidang ilmu akuntansi.

Terkait akan pentingnya penelitian ini dan seperti yang telah dipaparkan pada subbab sebelumnya bahwa perolehan hasil akademik seorang siswa terutama ditentukan oleh pendekatan pembelajaran (yaitu proses) yang dijalankan oleh siswa selama mereka menyelesaikan studi mereka, maka pengembangan penelitian akan diarahkan: 1) untuk menguji manfaat metode pendekatan cooperative learning yang diterapkan para mahasiswa akuntansi dalam mata kuliah Akuntansi Internasional, 2) untuk melihat adanya perbedaan perolehan hasil penelitian dari tujuan pertama, jika dengan mempertimbangkan pilihan pendekatan pembelajaran para mahasiswa yang mengampuh mata kuliah Akuntansi Internasional. Penelitian ini juga didorong oleh adanya fakta bahwa sebagian besar penelitian mengenai pendekatan pembelajaran siswa, sebelumnya telah dilakukan di beberapa negara maju seperti Amerika Serikat, 
Inggris Raya dan Hong Kong (Suhaiza Ismail, 2009). Oleh karena itu, penelitian ini juga ingin memberikan kontribusi dengan: (1) menyediakan wawasan baru tentang hubungan antara kinerja akademik dan pendekatan pembelajaran yang diadopsi terutama oleh mahasiswa akuntansi di Indonesia, khususnya dari perguruan tinggi swasta; serta (2) membantu pendidik untuk memahami pendekatan para mahasiswa didikan mereka dalam belajar.

\section{Kerangka Teori}

Berikut ini merupakan sajian prinsip-prinsip dasar yang mendasari pembelajaran yang efektif. Prinsipprinsip ini disaring dari beberapa penelitian dari berbagai disiplin ilmu (Anderson, J. R et al , 1989; Bandura, A. 1989; Clement, J.J. 1982; DiSessa, A. 1982; Dweck, C.S. 2002; Holyoak, K. J. 1984; Steele, C.M. dan Aronson, J. 1995; Walton, G. M., \& Cohen, G. L. 2007), yang di antaranya:

i. Pengetahuan awal para siswa dapat membantu ataupun menghambat proses pembelajaran mahasiswa/i angkatan baru pada tingkat pertama, masuk ke perguruan tinggi dengan pengetahuan, keyakinan, dan pola sikap yang telah diperoleh dari tingkat pendidikan sebelumnya maupun yang diperoleh melalui kehidupan seharihari. Ketika para siswa membawa pengetahuan ini ke dalam ruang kelas, tentunya hal ini akan mempengaruhi cara mereka dalam menyaring informasi dan menginterpretasikan materi yang mereka pelajari. Jika pengetahuan awal mereka cukup kuat dan akurat dan diaktifkan kembali pada waktu yang tepat, maka akan memberikan landasan yang kuat untuk membangun pengetahuan baru. Namun, ketika kualitas pengetahuan lemah, dan diaktifkan secara tidak tepat, ataupun tidak akurat, maka akan mengganggu serta menghambat proses pembelajaran baru. ii. Bagaimana cara siswa mengelola ilmu pengetahuan yang mereka miliki, akan memengaruhi metode pembelajaran dan cara penerapan ilmu tersebut.

Dalam proses para siswa untuk dapat memahami sebuah materi, mereka akan mencoba mengaitkan hubungan antar beberapa bagian-bagian (potongan-potongan) materi. Ketika koneksi tersebut membentuk struktur pengetahuan yang akurat dan penuh makna, maka siswa akan mampu menyerap dan menerapkan pengetahuan mereka secara efektif dan efisien. Sebaliknya, ketika pengetahuan terhubung dengan cara yang tidak akurat atau acak, maka siswa akan gagal dalam memahami pengetahuan tersebut serta menerapkannya dengan tepat.

iii. Motivasi para siswa akan menentukan, mengarahkan, serta mempertahankan pola belajar mereka. Ketika siswa memasuki perguruan tinggi dan memperoleh otonomi yang lebih besar atas apa, kapan, dan bagaimana mereka belajarr, maka motivasi memainkan peran penting dalam membimbing arah, intensitas, ketekunan, dan kualitas perilaku belajar. Ketika siswa menemukan nilai positif dalam tujuan atau kegiatan pembelajaran, dan berharap untuk berhasil (mampu mencapai hasil studi yang diinginkan), serta melihat adanya dukungan dari lingkungan sekitar, maka mereka akan cenderung menjadi sangat termotivasi untuk belajar

iv. Dalam hal penguasaan materi, siswa harus memiliki keterampilan (skills), melatih untuk mengintegrasikan-nya, dan tahu kapan harus menerapkan apa yang telah mereka pelajari.

Siswa harus mampu mengembangkan, tidak hanya keterampilan dan pengetahuan yang diperlukan untuk menyelesaikan tugas-tugas yang rumit, namun mereka juga harus melatih diri untuk mampu menggabungkan dan 
mengintegrasikan keterampilan dan pengetahuan tersebut. Pada akhirnya, siswa juga harus belajar kapan dan bagaimana menerapkan keterampilan dan pengetahuan yang mereka pelajari agar memperoleh hasil yang efektif.

v. Model praktik yang disesuaikan dengan tujuan pembelajaran dan digabungkan dengan umpan balik, akan meningkatkan kualitas pembelajaran siswa.

Proses pembelajaran dan perolehan hasil akademik yang baik, dapat dikembangkan ketika siswa terlibat dalam kegiatan praktik yang berfokus pada tujuan atau kriteria tertentu, dan dalam kegiatan praktik yang memiliki kuantitas serta frekuensi yang cukup guna memenuhi kriteria tersebut. Praktik harus diiringi dengan umpan balik yang secara eksplisit mengkomunikasikan tentang beberapa aspek kinerja, menyediakan informasi untuk membantu siswa dalam memenuhi kriteria tersebut, serta praktik juga harus diberikan pada waktu dan frekuensi yang tepat sehingga dapat bermanfaat.

vi. Proses pengembangan siswa erat kaitannya dengan lingkungan sosial, tingkat emosional, dan intelektual, yang kesemuanya akan memengaruhi proses pembelajaran.

Sebagai seorang manusia, siswa tidak hanya mempunyai intelektual namun juga memiliki sifat dasar makhluk sosial yang penuh dengan perasaan (emosi), dan mereka masih terus berupaya untuk mengembangkan tingkat intelektual, sosial, dan emosional tersebut. Walaupun kita (sebagai seorang pengajar) tidak dapat mengendalikan proses pengembangannya, namun kita masih dapat membentuk aspek intelektual, sosial, dan emosional, melalui atmosfer (iklim) kelas dengan beberapa pilihan metode yang sesuai. Faktanya adalah banyak penelitian yang menunjukkan bahwa iklim yang diciptakan akan berimplikasi pada para siswa. Iklim negatif dapat menghambat proses pembelajaran dan peningkatan kinerja akademik, tetapi di lain sisi iklim positif dapat memberikan energi dalam proses pembelajaran siswa.

vii. Agar menjadi seorang pelajar yang mandiri, siswa harus terbiasa untuk memantau dan menyesuaikan pendekatan pembelajaran mereka selama ini.

Sebagai seorang pelajar, mereka terlibat dalam berbagai proses metakognisi guna dapat memantau dan mengendalikan proses pembelajaran mereka; di antaranya mengevaluasi kekuatan dan kelemahan mereka sendiri, merencanakan pendekatan yang akan mereka gunakan, menerapkan dan memantau berbagai strategi, serta merefleksikan sejauh mana pendekatan mereka saat ini berfungsi dengan baik. Sayangnya, kebanyakan siswa cenderung tidak terlibat dalam proses ini secara alami, namun dengan bantuan berbagai media di antaranya media teknologi.

\section{Peran Metode Pendekatan Cooperative} Learning terhadap Kinerja Akademik Cooperative learning merupakan salah satu metode belajar yang dapat diterapkan oleh para individu yang berusia sebaya melalui berbagai tingkat kemampuan bekerja sama secara berpasangan atau dalam sebuah kelompok untuk mencapai tujuan tertentu. Masing-masing anggota kelompok memiliki tanggung jawab atas ketercapaian tujuan dan penguasaan materi setiap anggotanya. Dalam metode pembelajaran kooperatif ini, kegiatan pembelajaran diarahkan untuk menjadi lebih terstruktur dan dosen diharapkan mampu memberikan arahan yang lebih jelas. Penelitian ini akan dilaksanakan dengan menggunakan salah satu model pembelajaran kooperatif (Cooperative learning) y akni tipe Group Investigation $(G I)$ untuk diaplikasikan 
dalam kegiatan pembelajaran Akuntansi Internasional. Tipe ini dipilih karena diyakini dapat menghasilkan situasi belajar yang lebih efektif dalam sebuah kelompok belajar. Selain itu, tipe pembelajaran ini menggambarkan adanya keserasian komposisi antara fungsi dosen sebagai salah satu sumber belajar dan peran aktif mahasiswa dalam mengkonstruksi pengetahuan secara individual dan sosial. Dalam materi kuliah Akuntansi Internasional, terdapat beberapa konsep dan metode perhitungan yang perlu dibahas dari sebuah kasus, sehingga diharapkan melalui tipe pembelajaran kooperatif dengan jenis Group Investigation dapat membantu proses pemahaman para mahasiswa dan akhirnya berujung pada kinerja akademik yang memuaskan.

Hipotesa 1:

Terdapat hubungan yang signifikan secara statistik antara model pembelajaran dan prestasi

akademik

\section{Pendekatan Pembelajaran dan pengaruhnya secara moderasi terhadap Kinerja Akademik}

Sejak tahun 1970-an, beberapa penelitian terkait dengan isu pendekatan pembelajaran, secara khusus menganalisa dampaknya terhadap kinerja akademik para siswa (Biggs 2003; Enwistle 1998; Marton dan Booth 1997; Marton dan Soljo 1976; Marton dkk. 1997; Prosser dan Trigswell 1998; Ramsden 1979 dan 2003). Sejumlah besar penelitian juga turut mencoba menyelidiki hubungan antara pendekatan dalam belajar dan perolehan kinerja akademik siswa (Marton dan Saljo 1976; Ramsden 1992; Booth 1997; Booth et al. 1999; dan Prosser dan Trigwell 1998).

Dalam studi awal oleh Marton dan Saljo (1976) yang menyelidiki hubungan antara pendekatan dalam belajar dan kinerja akademik, mereka menemukan bahwa para siswa yang memiliki prestasi tinggi mengadopsi pendekatan mendalam saat belajar (deep approaches) sementara yang berprestasi rendah mengadopsi pendekatan permukaan (instrumental (surface) approaches). Temuan serupa juga berlaku di beberapa penelitian lain seperti Dahlgren (1984), Prosser dan Millar (1989), Bryne et al. (2002), Jackling (2005). Selain itu, beberapa peneliti termasuk Bryne et al. (2002), Jackling (2005), dan Paver dan Gammie (2005) dalam studi mereka ditemukan bahwa tidak hanya penggunaan pendekatan mendalam (deep approaches) memiliki dampak positif pada prestasi akademik, tetapi melaporkan bahwa hubungan serupa juga berlaku signifikan untuk pendekatan strategis (strategic approaches) dalam belajar.

Booth et al. (1999), dalam penelitian yang mereka lakukan kepada para mahasiswa akuntansi dari dua Universitas Australia, diperoleh temuan yang konsisten seperti penelitianpenelitian serupa, yakni terdapat hubungan antara penggunaan pendekatan permukaan (instrumental (surface) approaches) dan perolehan kinerja akademik yang rendah, meskipun demikian penelitian ini tidak menemukan hubungan yang signifikan antara kinerja akademik yang tinggi dan penerapan pendekatan mendalam (deep approaches). Sebaliknya, dalam penelitian yang dilakukan oleh Davidson (2002) terdapat hubungan positif yang signifikan antara pendekatan pembelajaran dan perolehan hasil akademik, khususnya pada kualitas soal ujian yang lebih rumit (kompleks), tetapi hubungan serupa tidak berlaku untuk pertanyaan-pertanyaan soal ujian yang sederhana (kurang kompleks), sedangkan untuk pendekatan permukaan (instrumental (surface) approaches) tidak terdapat hubungan yang signifikan. Sementara sebuah penelitian yang dikembangkan oleh Duff (2003) menunjukkan tidak ada hubungan yang signifikan antara perolehan kinerja akademik siswa dan pendekatan pembelajaran yang diterapkan dalam mempelajari modul manajemen keuangan. Sedangkan pada penelitian 
terkini yang dilakukan oleh Suhaiza Ismail (2009) kepada para mahasiswa Akuntansi di Universitas Indonesia menemukan adanya korelasi antara kinerja akademik dan pendekatan pembelajaran strategis dengan tingkat korelasi tertinggi dibandingkan dengan pendekatan pembelajaran lainnya dan nilai korelasi tersebut signifikan pada tingkat 1 persen.

Meskipun masih banyak temuantemuan yang tidak konsisten, sebagian besar penelitian menyatakan bahwa terdapat hubungan antara pendekatan pembelajaran yang digunakan dengan perolehan kinerja akademik, di mana sebagian besar (mayoritas) peneliti setuju bahwa pendekatan mendalam saat belajar (deep approaches) berhubungan positif dengan hasil atau kinerja akademik siswa, sementara penggunaan pendekatan permukaan dikaitkan dengan perolehan kinerja yang lebih rendah.

Hipotesa 2:

Terdapat hubungan signifikan secara statistik antara model pembelajaran dan prestasi akademik, yang pengaruhnya diperkuat melalui adanya pilihan pendekatan pembelajaran para mahasiswa

\section{Metodologi Penelitian Prosedur Penelitian}

Responden dari penelitian ini akan terdiri dari para mahasiswa yang mengambil mata kuliah Akuntansi Internasional di Semester 8 tahun ajaran 2018/2019. Para mahasiswa ini sedang menempuh studi strata satu dalam mengejar gelar Sarjana mereka di bidang Akuntansi dan Keuangan, di mana mata kuliah tersebut di atas merupakan mata kuliah pilihan bagi semua mahasiswa akuntansi.

Penelitian ini bertujuan untuk menilai model pembelajaran yang diterapkan dalam mempelajari mata kuliah Akuntansi Internasional karena merupakan mata pelajaran akuntansi keuangan yang dipelajari oleh para mahasiswa, dan ditempuh bersamaan dengan kuliah Akuntansi Keuangan Lanjutan 2 dan Perpajakan Internasional yang beberapa materinya beririsan dengan Akuntansi Internasional. Survei dilakukan pada minggu ke 4 Semester 8, tahun ajaran 2018/2019 selama masa perkuliahan formal, di mana para mahasiswa diberi sekitar 20 menit untuk menanggapi kuesioner. Para mahasiswa juga diingatkan untuk memberikan jawaban jujur atas semua item tertera dalam kuesioner dan diberitahu bahwa tidak ada jawaban yang benar atau salah untuk kesemua item tersebut. Selain itu, mereka juga perlu diyakinkan bahwa tanggapan mereka dalam kuesioner tersebut akan diperlakukan secara anonim, dan sama sekali tidak akan mempengaruhi nilai ujian mereka.

Setelah itu, teknik pengumpulan data berikutnya adalah dengan menggunakan teknik observasi, tes dan dokumentasi. Menurut Sudjana (2000:114) mengatakan "Observasi adalah teknik pengumpulan data dengan pengamatan kepada tingkah laku pada situasi tertentu". Observasi dijadikan sampel untuk mendapatkan gambaran secara langsung akan kegiatan belajar mahasiswa, sehingga data diperoleh secara langsung dengan mengamati kegiatan para mahasiswa. Dengan demikian data tersebut dapat bersifat objektif dalam menggambarkan aspekaspek kepribadian mahasiswa menurut keadaan yang sebenarnya. Adapun tindakan yang dilakukan peneliti dalam penelitian ini adalah :

a. Melakukan pre test terhadap mahasiswa, untuk pengumpulan data.

b. Mempersiapkan rencana penerapan model pembelajaran Group Investigation dengan terlebih dahulu memberitahukannya kepada mahasiswa.

c. Menerapkan model Group Investigation pada materi akuntansi internasional.

d. Melakukan post test untuk pengumpulan data. 
e. Mengolah dan menganalisis data.

f. Menyusun laporan.

Keseluruhan teknik pengumpulan ini dilakukan secara bersamaan di sela-sela perkuliahan dan kurang lebih menghabiskan waktu hingga hampir 2 (dua) jam.

\section{Pengembangan Instrumen Penelitian}

The Approaches and Study Skills Inventory for Students (ASSIST) yang dikembangkan oleh EnUvistle dan Tait pada tahun 1996, akan diadaptasi dan digunakan untuk mengukur pendekatan pembelajaran yang diadopsi oleh siswa akuntansi dan terdiri dari dua bagian. Bagian A dari kuesioner mensyaratkan responden untuk melengkapi informasi latar belakang yang meliputi informasi seperti nomor identifikasi siswa dan hasil indeks prestasi kumulatif (IPK) terakhir. Bagian B dari kuesioner bertujuan untuk mengeksplorasi serta mengukur pendekatan responden dalam belajar. Pada bagian ini, responden diminta untuk menunjukkan persepsi mereka atau persetujuan atas pernyataan-pernyataan yang diberikan dengan skala Likert lima poin (skor $4=$ sangat setuju, skor $3=$ setuju, skor $2=$ tidak setuju, dan skor $1=$ sangat tidak setuju). Sedangkan untuk pencapaian kinerja akademik akan diukur berdasarkan perolehan nilai akhir dari hasil tes (Post-Test) dan kemudian disinkronkan dengan perolehan IPK terkini.

\section{Teknik Analisis Data}

Dalam menganalisis data, beberapa uji statistik yang relevan akan dilakukan dengan menggunakan SPSS. Khususnya, hasil statistik deskriptif seperti rata-rata, standar deviasi, nilai minimum dan maksimum yang diperoleh untuk melaporkan hasil temuan pada pendekatan pembelajaran yang lebih banyak diadopsi oleh para mahasiswa akuntansi dalam mempelajari mata kuliah Akuntansi Internasional.

Dalam meneliti hubungan antara pendekatan pembelajaran dan akademik kinerja, korelasi spearman juga akan dilakukan. Terakhir, ANOVA (Univariate Analysis of Variance) dan Ttest merupakan jenis uji yang paling sering digunakan dalam penelitian pendidikan. Perbedaan dari T-test dan ANOVA hanya jumlah kelompok sampel yang dibandingkan. T-test menguji perbedaan dari dua kelompok dalam satu variabel terikat. ANOVA menguji perbedaan dua atau lebih kelompok dalam satu variabel terikat. Contoh aplikasi dari ANOVA adalah membandingkan 4 kelompok (pria, wanita, tua, muda) dalam hal waktu yang dihabiskan untuk membaca (Cresswell, 2012: 339).

Teknik analisis data yang digunakan dalam penelitian ini menggunakan Repeated-Measures ANOVA. Menurut Field (2009: 458) Repeated-measures digunakan karena subjek yang sama berpartisipasi dalam suatu eksperimen dengan dua perlakuan atau lebih. Dalam penelitian ini eksperimen yang dilakukan memiliki dua perlakuan (pertemuan I untuk materi I dan pertemuan II untuk materi II) dan variabel terikat yang diuji lebih dari satu (keakuratan dan kecepatan pemecahan masalah). Selain itu, Field (2009: 17) menjelaskan bahwa jika menggunakan analisis Repeated-measures, efek dari eksperimen lebih jelas serta dapat menentukan ada atau tidaknya interaksi (ketergantungan) antara variabelvariabel.

Beberapa asumsi dari ANOVA harus dipenuhi dahulu sebelum menganalisis dan menyimpulkan hasil dari penelitian. Field (2009: 359 - 360) menjabarkan ANOVA memiliki tiga asumsi yang harus dipenuhi. Asumsiasumsi ANOVA akan dijabarkan sebagai berikut:

\section{Normalitas}

Data yang memiliki distribusi normal berarti memiliki sebaran yang normal pula. Data akan berdistribusi normal apabila nilai skewness dan kurtosis akan berada diantara -2 dan +2 (George \& 
Mallery, 2010). Selain itu, Field (2009: 144) menjelaskan bahwa KolmogorovSmirnov test ( $K-S$ Test) juga dapat menjadi pertimbangan data berdistribusi normal jika nilai signifikansi $(p)$ lebih dari 0,05. Field (2009: 134) juga memberikan alternatif lain yang menyatakan data dapat dikatakan mendekati berdistribusi normal jika sampel penelitian lebih dari 30. Dengan kata lain, data berdistribusi normal dapat mewakili populasi dalam penelitian (Field, 2009: 133).

Uji normalitas lainnya yang tidak hanya mengacu pada data numerik, dapat menggunakan grafik $Q Q$-Plot. Pada $Q-Q$ Test menghasilkan grafik $Q-Q$ plot yang dapat menggambarkan persebaran distribusi data.

\section{Homogenitas varians}

Asumsi homogenitas bertujuan untuk mengetahui apakah varians skor (variansi antar kelompok sampel) yang diukur sama atau tidak (Field, 2009: 133). Pada analisis Repeated-measures, asumsi homogenitas varians skor akan terpenuhi jika sudah memenuhi assumption of sphericity (circularity) atau compound symmetry. Apabila variabel terikat hanya dua (dalam hal ini menggunakan Repeated-measures ANOVA) maka tidak perlu menguji asumsi sphericity karena varians skor cenderung tidak memilki perbedaan varians skor atau cenderung sama (Field, 2009: 459).

ini penjelasan analisis uji hipotesis yang terdiri dari tiga:

\section{Uji hipotesis pertama}

Untuk mengetahui perbedaan efektivitas antara model pembelajaran yakni tipe Group Investigation (GI) dibandingkan dengan model individu yang ditinjau dari keakuratan jawaban tes para mahasiswa. Analisis uji hipotesis dalam penelitian ini dilakukan menggunakan Repeatedmeasures ANOVA. Berikut ini penjelasan analisis uji hipotesis yang terdiri dari:
Selain itu, uji Levene's digunakan untuk mengetahui homogenitas dari variabel yang akan diuji. Data dikatakan homogen ketika nilai signifikansi lebih dari 0,05. Menurut Kirk (1995: 100), uji F tetap robust (kuat) walaupun asumsi homogenitas varians tidak terpenuhi dengan syarat (1) siswa berjumlah sama pada setiap kelompok, (2) asumsi normalitas tepenuhi, (3) perbandingan antara varians terbesar dengan varians terkecil tidak melebihi 3. Peneliti menggunakan analisis Repeatedmeasures ANOVA.

\section{Pengamatan Sampel Penelitian Saling Independen}

Pengamatan pada semua kelompok eksperimen (sampel) dilakukan secara independen dan acak satu sama lain. Saling independen dalam hal ini jika setiap pengukuran antarkelompok yang diteliti tidak saling mempengaruhi atau dipengaruhi. (Field, 2009: 603). Myers (1979) menjelaskan, asumsi independensi dapat dipenuhi apabila setiap subjek hanya dikenai pengukuran satu kali pelaksanaan dan masing-masing subjek ditempatkan secara acak (randomly assigned) ke dalam kelompok eksperimen.

Analisis uji hipotesis dalam penelitian ini dilakukan dengan menggunakan Repeated-measures ANOVA. Berikut

H0 : tidak terdapat perbedaan pengaruh penerapan model antara model pembelajaran yakni tipe Group Investigation $(G I)$ dibandingkan dengan model individu yang ditinjau dari keakuratan jawaban tes para mahasiswa.

H1 : terdapat perbedaan pengaruh penerapan model antara model pembelajaran yakni tipe Group Investigation $(G I)$ dibandingkan dengan model individu yang ditinjau dari keakuratan jawaban tes para mahasiswa. 
Apabila nilai signifikansi $(p)<0,10$ maka $H 0$ ditolak, artinya terdapat perbedaan pengaruh penerapan model antara model pembelajaran yakni tipe Group Investigation (GI) dibandingkan dengan model individu yang ditinjau dari keakuratan jawaban tes para mahasiswa.

Sebaliknya, apabila nilai signifikansi $(p)$ $\geq 0,10$ maka $H 0$ diterima, artinya tidak terdapat perbedaan pengaruh penerapan model antara model pembelajaran yakni tipe Group Investigation (GI) dibandingkan dengan model individu yang ditinjau dari keakuratan jawaban tes para mahasiswa.

\section{Uji hipotesis kedua}

Untuk mengetahui apakah terdapat hubungan signifikan secara statistik antara model pembelajaran dan prestasi akademik, yang pengaruhnya diperkuat melalui adanya pilihan pendekatan pembelajaran para mahasiswa

Pengaruh moderasi tersebut akan diuji melalui uji interaksi (Moderated Regression Analysis) yang merupakan aplikasi dari regresi linear berganda di mana dalam persamaannya mengandung unsur interaksi (perkalian dua/lebih

variabel independen). Analisis uji hipotesis dalam penelitian ini terdiri dari:

H0 : tidak terdapat pengaruh moderasi secara signifikan atas pilihan pendekatan pembelajaran para mahasiswa dalam hubungan antara model pembelajaran (Group Investigation) dan prestasi akademik
H1 : terdapat pengaruh moderasi secara signifikan atas pilihan pendekatan pembelajaran para mahasiswa dalam hubungan antara model pembelajaran (Group Investigation) dan prestasi akademik

Apabila nilai signifikansi $(p)<0,10$ maka $H 0$ ditolak, artinya terdapat pengaruh moderasi secara signifikan atas pilihan pendekatan pembelajaran para mahasiswa dalam hubungan antara model pembelajaran (Group Investigation) dan prestasi akademik

Sebaliknya, apabila nilai signifikansi $(p)$ $\geq 0,10$ maka $H 0$ diterima, artinya tidak terdapat pengaruh moderasi secara signifikan atas pilihan pendekatan pembelajaran para mahasiswa dalam hubungan antara model pembelajaran (group investigation) dan prestasi akademik

\section{Pembahasan}

\section{Hasil Uji}

\section{Melakukan Pre-test}

Mahasiswa yang diberi pre-test adalah mahasiswa yang dijadikan sampel dalam penelitian ini yaitu 2 kelas yang diasuh, yang terdiri dari kelas Akuntansi A pagi dan kelas akuntansi B malam, yang mahasiswanya berjumlah 75 orang secara keseluruhannya.

Berikut ini tabel hasil pre-test keseluruhan jumlah siswa yang mengikuti pre-test tersebut: 
Tabel 1

Rekapitulasi Nilai dari hasil Pre test semester 8 kelas A dan kelas B

\begin{tabular}{|c|c|c|c|c|c|c|}
\hline \multirow{2}{*}{ No } & \multirow{2}{*}{ Kategori } & \multirow{2}{*}{ Nilai } & \multicolumn{2}{|c|}{ Kelas } & \multirow{2}{*}{$\begin{array}{c}\text { Jumlah } \\
\text { Mahasiswa }\end{array}$} & \multirow{2}{*}{ Persentase } \\
\cline { 4 - 5 } & & & A & B & & \\
\hline 1 & Kurang & $51 \geq \ldots$. & 8 & 6 & 14 & $18.7 \%$ \\
\hline 2 & Sedang & $52-60$ & 13 & 10 & 23 & $30.7 \%$ \\
\hline 3 & Cukup & $61-70$ & 9 & 8 & 17 & $22.6 \%$ \\
\hline 4 & Baik & $71-79$ & 7 & 6 & 13 & $17.3 \%$ \\
\hline 5 & Sangat Baik & $\ldots . . \geq 80$ & 5 & 3 & 8 & $10.7 \%$ \\
\hline & & Sub - total & 42 & 33 & & $100 \%$ \\
\hline
\end{tabular}

Dapat dilihat pada tabel tersebut di atas bahwa sebaran hasil tes sebelum model Group Investigation diterapkan, sekitar hampir setengah dari kinerja akademik para mahasiswa berada pada kategori kurang dan sedang (kurang lebih 49.4\%). Di lain pihak, untuk kategori sangat baik, hanya mampu diisi oleh sekitar sepuluh persen $(10.7 \%)$ dari jumlah sampel yang ada.

Berikut ini grafik hasil pre-test keseluruhan jumlah siswa yang mengikuti pre-test tersebut:

Grafik 1

Rekapitulasi Nilai dari hasil Pre test semester 8 kelas A dan kelas B

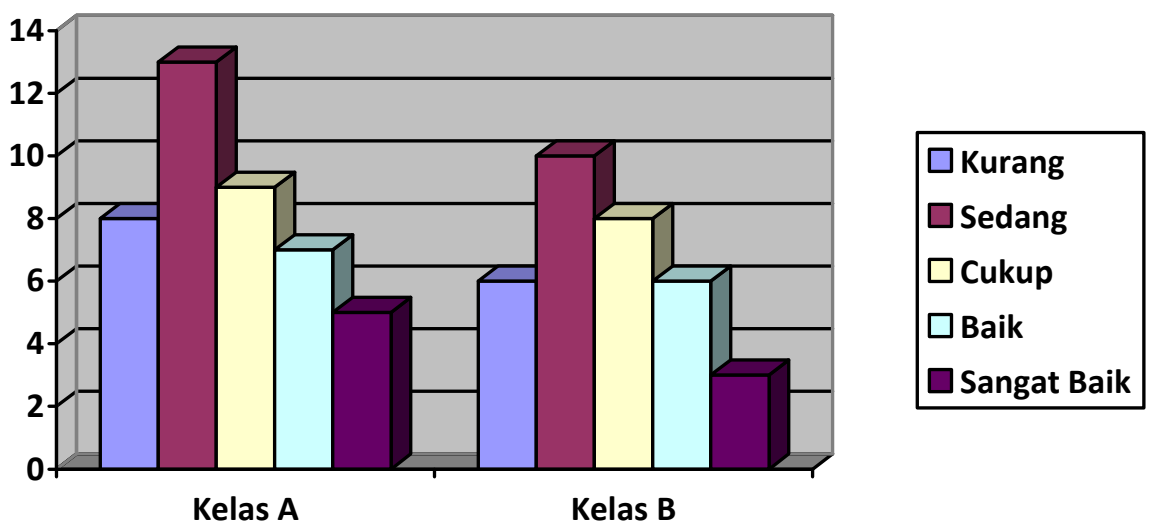

\section{Melakukan Post-test}

Mahasiswa yang juga melakukan post-test adalah mahasiswa yang sama dengan sampel pada pre-test sebelumnya yaitu 2 kelas yang diasuh, yang terdiri dari kelas Akuntansi A pagi dan kelas akuntansi B malam, yang mahasiswanya berjumlah 75 orang secara keseluruhannya. Berikut ini tabel hasil post-test keseluruhan jumlah siswa yang mengikuti post-test tersebut: 
Tabel 2

Rekapitulasi Nilai dari hasil Post-test semester 8 kelas A dan kelas B

\begin{tabular}{|c|c|c|c|c|c|c|}
\hline \multirow{2}{*}{ No } & \multirow{2}{*}{ Kategori } & \multirow{2}{*}{ Nilai } & \multicolumn{2}{|c|}{ Kelas } & \multirow{2}{*}{$\begin{array}{c}\text { Jumlah } \\
\text { Mahasiswa }\end{array}$} & \multirow{2}{*}{ Persentase } \\
\cline { 4 - 5 } & & & A & B & & \\
\hline 1 & Kurang & $51 \geq \ldots$. & 5 & 3 & 8 & $10.7 \%$ \\
\hline 2 & Sedang & $52-60$ & 8 & 5 & 13 & $17.3 \%$ \\
\hline 3 & Cukup & $61-70$ & 15 & 12 & 27 & $36 \%$ \\
\hline 4 & Baik & $71-79$ & 9 & 9 & 18 & $24 \%$ \\
\hline 5 & Sangat Baik & $\ldots . .80$ & 5 & 4 & 9 & $12 \%$ \\
\hline & & Sub - total & 42 & 33 & & $100 \%$ \\
\hline
\end{tabular}

Dapat dilihat pada tabel tersebut di atas bahwa sebaran hasil tes sesudah penerapan model Group Investigation diterapkan, hanya tersisa sekitar kurang dari sepertiga mahasiswa yang berada pada kategori kurang dan sedang (kurang lebih $28 \%$ ). Selebihnya, dapat dikatakan mayoritas berada di sekitar kategori cukup sampai dengan sangat baik dan khusus untuk kategori sangat baik, mengalami peningkatan menjadi dua belas persen $(12 \%)$.

Berikut ini grafik hasil post-test keseluruhan jumlah siswa yang mengikuti post-test tersebut:

Grafik 2

Rekapitulasi Nilai dari hasil Post-test semester 8 kelas A dan kelas B

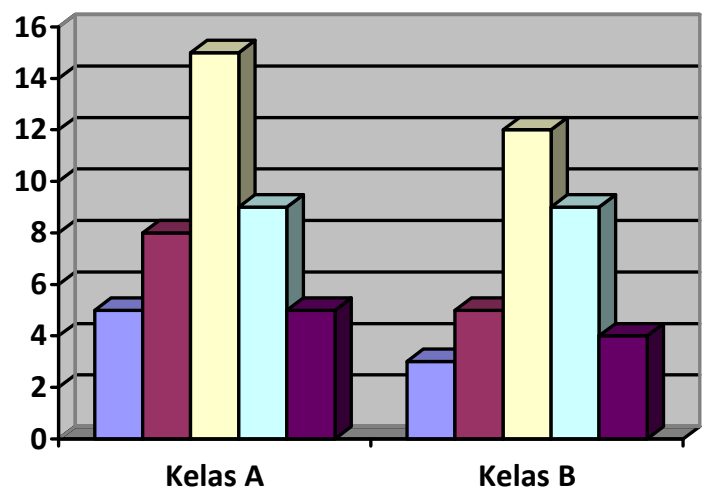

\begin{tabular}{|l|}
\hline Kurang \\
$\square$ Sedang \\
$\square$ Cukup \\
$\square$ Baik \\
$\square$ Sangat Baik
\end{tabular}


Hasil Uji ANOVA (Peran Metode Pendekatan Cooperative Learning - GI terhadap Kinerja Akademik)

Berikut akan dipaparkan hasil pengolahan data-data dari uji Independent Sample t-Test. Hasil uji perbedaan di tahap awal, baik hasil kinerja berupa total nilai (dari masingmasing kategori) yang dihasilkan oleh setiap mahaiswa yang berasal dari Pretest maupun Post-test dapat dilihat pada Tabel 5.3. di bawah ini :

Tabel 3.

Hasil Uji Independent Sample t-Test - Perbandingan Kinerja Akademik antara Sebelum dan Sesudah penerapan Group Investigation (GI)

Anova: Single Factor

SUMMARY

\begin{tabular}{|c|c|c|c|c|c|c|}
\hline Groups & Count & Sum & Average & Variance & & \\
\hline Before GI & 5 & 3072 & 614.4 & 35873.3 & & \\
\hline After GI & 5 & 7696 & 1539.2 & 1187083 & & \\
\hline \multicolumn{7}{|l|}{ ANOVA } \\
\hline $\begin{array}{l}\text { Source of } \\
\text { Variation }\end{array}$ & SS & $d f$ & $M S$ & $F$ & $P$-value & $F$ crit \\
\hline Between Groups & 2138138 & 1 & 2138138 & 3.49667 & 0.098416 & 5.317655 \\
\hline Within Groups & 4891826 & 8 & 611478.3 & & & \\
\hline Total & 7029964 & 9 & & & & \\
\hline
\end{tabular}

Dari hasil uji independent sample t-test yang telah dilakukan maka dapat dilihat perolehan nilai $P$-value sebesar 0.098416 dan nilai tersebut lebih kecil dari tingkat signifikansi $10 \% \quad(<0.10)$. Dengan demikian, berarti terdapat perbedaan yang signifikan antara hasil kinerja akademik baik sebelum ataupun sesudah penerapan penerapan model pembelajaran yakni tipe Group Investigation (GI) di kelompok eksperimen.

Penerapan model group investigation dalam proses pembelajaran mata kuliah Akuntansi Internasional sangatlah berpengaruh terhadap kompetensi akuntansi mahasiswa, terutama pada materi-materi yang beririsan dengan mata kuliah Akuntansi Keuangan Lanjutan dan Perpajakan Internasional. Hal ini dikarenakan di dalam kedua mata kuliah tersebut mahasiswa dituntut untuk dapat menyusun laporan keuangan translasi, perlakuan akuntansi untuk lindung nilai dan bagaimana pengaruh transfer pricing terhadap penerapan standar perpajakan antar negara. Namun pada materi kuliah Akuntansi Keuangan Lanjutan, penyusunan translasi tidak terlalu dipertajam. Oleh karena itu diharapkan dengan adanya model pembelajaran yang bervariasi dalam kegiatan belajar mengajar tentu dapat membuat suasana belajar yang lebih kondusif. Terutama suasana yang mendukung tersebut akan 
tercapai dengan adanya model pembelajaran kooperatif sehingga menjadi tidak membosankan, selain itu dalam model pembelajaran group investigasi ini juga pembelajaran tidak hanya berpusat pada dosen saja, tetapi kepada para mahasiswa. Sehingga dengan terciptanya suasana belajar yang menyenangkan dan bervariasi tentu akan meningkatkan kompetensi belajar mahasiswa. Hal ini sesuai dengan pendapat Dick dan Reiser (dalam Bambang Warsita, 2008: 288), yang menyatakan "pembelajaran efektif adalah suatu pembelajaran yang memungkinkan peserta didik untuk belajar keterampilan spesifik, ilmu pengetahuan, dan sikap serta yang membuat peserta didik senang dan nyaman". Jadi dapat dikatakan bahwa ketika mahasiswa senang dalam belajar, mereka akan mudah menyerap ilmu yang diberikan oleh para dosen.

\section{Pendekatan Pembelajaran dan Pengaruhnya secara moderasi terhadap Kinerja Akademik}

Berikut akan dipaparkan hasil pengolahan data-data dari uji moderasi Hasil uji moderasi atas variabel model pendekatan pembelajaran yang diterapkan para mahasiswa (Strategic) dalam hubungan antara model pembelajaran (Group Investigation) dan prestasi akademik dapat dilihat pada Tabel 5.4. di bawah ini :

Tabel 4.

Hasil Uji Moderasi - $R$ Square atas variabel Model Pendekatan Pembelajaran yang diterapkan para mahasiswa dalam hubungan antara Model Pembelajaran (Group Investigation) dan Prestasi Akademik

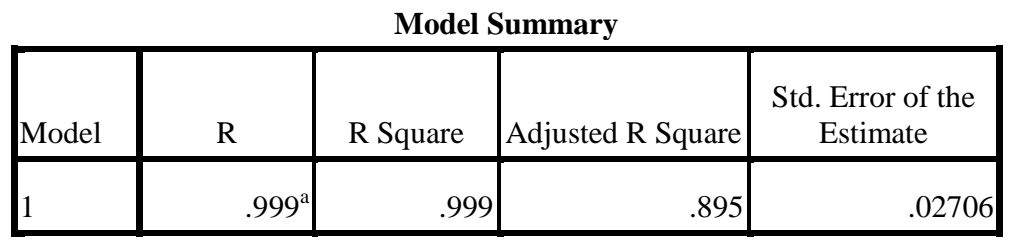

a. Predictors: (Constant), GIxStrategic, Strategic, GI

Nilai Adjusted $R$ Square yang dihasilkan dalam model penelitian kali ini adalah sebesar $89.5 \%$ sehingga dapat disimpulkan bahwa dengan adanya penerapan pendekatan pembelajaran Strategic dapat memperkuat hubungan antara model pembelajaran (Group
Investigation) dan prestasi akademik para mahasiswa Akuntansi, khususnya dalam mengampuh mata kuliah Akuntansi Internasional. Sedangkan untuk sisany sebesar $11.5 \%$ dipengaruhi oleh variabelvariabel lain yang tidak turut diteliti dalam penelitian ini. 
Tabel $5 \mathrm{i}$

Hasil Uji Signifikansi atas Pengaruh Moderasi Model Pendekatan Pembelajaran yang diterapkan para mahasiswa dalam hubungan antara Model Pembelajaran (Group Investigation) dan Prestasi Akademik

\begin{tabular}{|c|c|c|c|c|c|c|}
\hline \multicolumn{7}{|c|}{ ANOVA $^{b}$} \\
\hline \multicolumn{2}{|c|}{ Model } & Sum of Squares & df & Mean Square & $\mathrm{F}$ & Sig. \\
\hline 1 & Regression & .647 & 3 & .216 & 294.277 & $.043^{\mathrm{a}}$ \\
\hline & Residual & .001 & & .001 & & \\
\hline & Total & .647 & 2 & & & \\
\hline
\end{tabular}

a. Predictors: (Constant), GIxStrategic, Strategic, GI

b. Dependent Variable: Y

Hasil tabel di atas mendukung kesimpulan sebelumnya (Adjusted $R$ Square) di mana dapat dilihat bahwa dari model penelitian yang diajukan dalam penelitian ini; memiliki tingkat signifikansi sebesar 0.043 yang berarti signifikan dengan nilai signifikansi $(p)<$ 0,05 . Berikut ini adalah model penelitian yang diujikan:

$\mathrm{Y}=1.292+0.416$ Strategic $-0.019 \mathrm{GI}+$ 0.034 Strategic x GI + e

Tabel 5.ii

Hasil Uji Signifikansi atas Pengaruh Moderasi Model Pendekatan Pembelajaran yang diterapkan para mahasiswa dalam hubungan antara Model Pembelajaran (Group Investigation) dan Prestasi Akademik

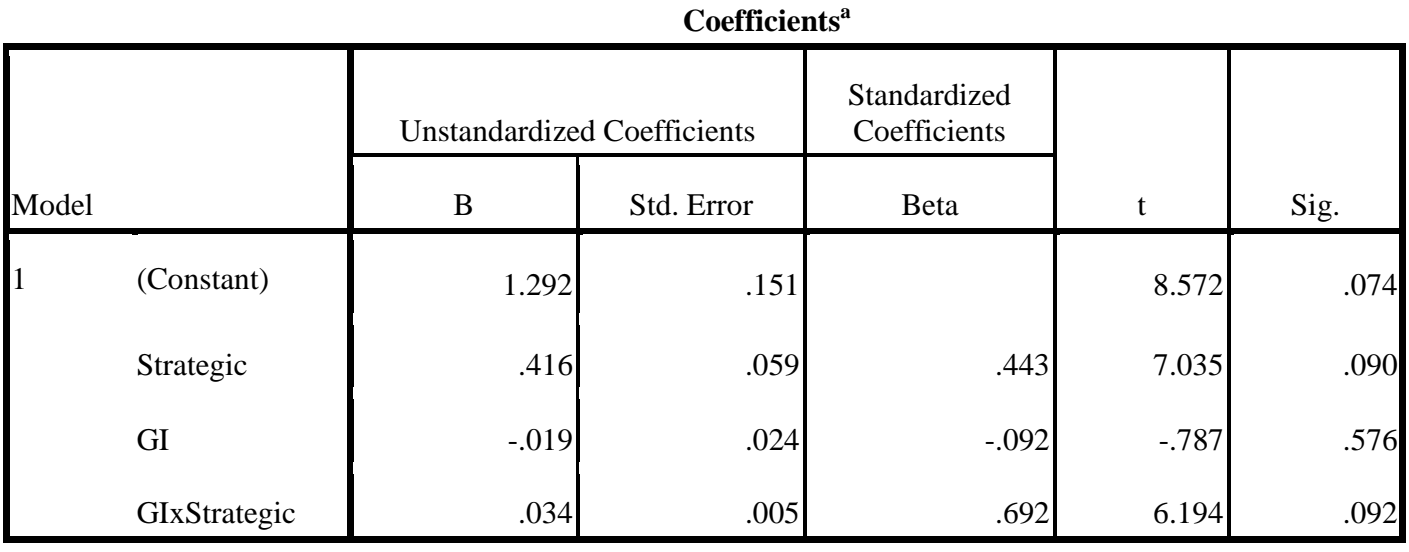

a. Dependent Variable: Y 
Dapat dilihat dari Tabel 5.5.ii bahwa nilai signifikansi atas variabel moderasi berupa penerapan pilihan pendekatan pembelajaran yakni Strategic yang memperkuat hubungan antara metode pembelajaran (Group Investigation) dan kinerja akademik adalah sebesar 0.092 yang berarti signifikan dengan nilai signifikansi $(p)<0,10$. Hal tersebut dimungkinkan untuk terjadi mengingat dalam praktek metode pembelajaran (Group Investigation); mahasiswa akan dapat meningkatkan kompetensi belajarnya karena suasana belajar yang lebih kondusif dan ilmiah (dicirikan dengan adanya diskusi antar anggota kelompok). Hal ini dapat dibuktikan dengan hasil post-test yang dilakukan, di mana dari hasil post-test terlihat adanya peningkatan kompetensi akuntansi dari para mahasiswa dalam mata kuliah Akuntansi Internasional.

Lebih lanjut dapat disimak bahwa keberadaan hubungan antara metode pembelajaran (Group Investigation) dengan hasil kinerja akademik ternyata juga dapat turut diperkuat melalui pilihan pendekatan pembelajaran dari masingmasing mahasiswa. Dalam hal ini, mayoritas mahasiswa yang masuk dalam sampel penelitian cenderung untuk menggunakan pendekatan Strategic. Di mana dalam pendekatan tersebut, mahasiswa akan berupaya semaksimal mungkin untuk memahami metode penilaian para dosen serta memperhatikannya dengan baik agar nantinya dapat mengarahkan (memberikan panduan) bagi mereka saat menghadapi ujian maupun saat mengerjakan tugas-tugas kuliah, sehingga nilai yang diperoleh akan memuaskan. Tentunya pendekatan seperti ini akan memperkuat model pembelajaran lewat metode (Group Investigation), dikarenakan mahasiswa menjadi dimampukan untuk dapat lebih memahami materi melalui pertukaran informasi dalam sebuah kelompok dan kemudian mengarahkan pemahaman tersebut (di saat mengerjakan tugas maupun ujian) agar sesuai dengan standar penilaian dosen, yang kemudian berujung pada kinerja akademik yang memuaskan.

\section{Kesimpulan}

Dari data yang ada dan berdasarkan hasil penelitian maka kesimpulan yang diperoleh adalah :

1 Dari hasil pre-test yang dilakukan maka dapat diketahui bahwa kompetensi mahasiswamahasiswa akuntansi dalam mata kuliah Akuntansi Internasional cukup rendah dan tentunya hasil ini diperoleh sebelum dilakukan model pembelajaran kooperatif.

2 Penerapan model group investigation pada perkuliahan Akuntansi Internasional berdampak pada peningkatan motivasi dan minat belajar mahasiswa, meningkatkan keaktifan mahasiswa dalam pembelajaran, sekaligus juga mengajarkan kepada mahasiswa untuk berempati dan saling menghargai serta memahami suatu hal melalui berbagai sudut pandang.

3 Model pembelajaran group investigation yang digunakan pada mata kuliah Akuntansi Internasional sangatlah effektif dalam meningkatkan kompetensi mahasiswa dan keefektifannya turut diperkuat melalui pilihan pendekatan pembelajaran yang diterapkan mahasiswa (Strategic).

\section{Daftar Pustaka}

Anderson, J. R., Conrad, F. G., Corbett, A. T. (1989). Skill acquisition and the LISP tutor. Cognitive Science, 13(4), 467-505.

Bandura, A. (1989). Self-regulation of motivation and action through internal standards and goal systems. In L. A. Pervin (Ed.), 
Goal concepts in personality and social psychology (pp. 19-85). Hillsdale, NJ: Erlbaum.

Biggs. "Individual Differences in Study Processes and the Quality of Learning Outcomes." Higher Education 8 (1979): 381-394. Students Approaches to Learning and Studying. Melbourne, Victoria: Australian Council for Education Research, 1987b. . Teaching for Quality Learning at University 2nd. Buckingham: Society for Research into Higher Education and Open University Press, 1987a.

Bryne et al. "Approaches to Learning: Irish Students of Accounting." Irish Accounting Review 6, no. 2 (1999): 1-29.

"The Relationship between Learning Approaches and Learning Outcomes: A Study of Irish Accounting Students." Accounting Education: an International Journal 11, no. 1 (2002): 27-42.

Clement, J.J. (1982). Students' preconceptions in introductory mechanics. American Journal of Physics, 50, 66-71.

Davidson. "Relationship of Study Approach and Exam Performance." Journal of Accounting Education 20, no. 1 (2002): 29-44.

DiSessa, A. (1982). Unlearning Aristotelian physics: A study of knowledge-based learning. Cognitive Science, 6, 37-75.

Dweck, C.S. (2002). Beliefs that make smart people dumb. In R.J. Sternberg (Ed.), Why smart people can be so stupid (pp. 24-41). New Haven, CT: Yale University Press.

Entwistle and P. Ramsden. Understanding Student Learning. London: CroomHelm, 1987.

Entwistle. Approaches to Learning and Forms $o$ f Understanding. In Teaching and Learning in Higher Education, edited by B. Dart and
G. Boulton-Lewis. Melbourne: Australian Council for Educational Research, 1998.

Holyoak, K. J. (1984). Analogical thinking and human intelligence. In R. J. Sternberg (Ed.), Advances in the Psychology of Human Intelligence, Vol. 2 (pp. 199-230).

Hillsdale, NJ: Erlbaum.Jackling. "Perceptions of the Learning Context and Learning Approaches: Implications for Quality Learning Outcomes in Accounting." Accounting Education: An International Journal 14, no. 3 (2005): 271-291.

Lucas. "Deep and Surface Approaches to Learning Within Introductory Accounting: A Phenomenographic Study." Accounting Education 10, no. 2(2001): 161-184.

Marton and Booth. Learning and Awareness. New Jersey: Lawrence Erlbaum Associates, 1997.

Marton and Saljo. "On Qualitative Differences in Learning: Outcome and Process." British Journal of Educational Psychology 46 (1976): 4-11.

Paver and Gammie. "Constructed Gender, Approach to Learning and Academic Performance." Accounting Education: an International Journal 14, no. 4 (2005): 427-444.

Prosser and Trigwell. Understanding Learning and Teaching: The Experience in Higher Education. Buckingham: Open University Press, 1999

Ramsden, P. Learning to Teach in Higher Education. London: Kogan Page, 1992. _ Learning to Teach in Higher Education. London, New York: Routledge Falmer, 2003.

Ramsden, "Student Learning and Perceptions of the Academic Environment." Higher Education 8 (1979): 411-427.

Richardson and King. "Gender Differences in the Experience of 
Higher Education: Quantitative and Qualitative Approaches." Educational Psychology 11 (1991): 363-382.

Severiens and Ten Dame. "Gender Differences in Learning Styles: A Narrative Review and Quantitative Meta-analysis." Higher Education 27 (1994): 487-501.

Steele, C.M. \& Aronson, J. (1995). Stereotype threat and the intellectual test performance of African Americans. Journal of Personality and Social Psychology, 69 (5), 797-811.

Suhaiza Ismail "Accounting Student;s Learning Approaches and Impact on Academic Performance" Jurnal Akuntansi dan Keuangan Indonesia Volume 6 Nomor 2, Desember 2009
Svensson, L. "On Qualitative Differences in Learning: III - Study Skills and Learning." British Journal o $f$ Educational Psychology 47 (1977): 233-234.

Walton, G. M., \& Cohen, G. L. (2007). A question of belonging: race, social fit, and achievement. Journal of Personality and Social Psychology, 92 (1), 82-96. 